\title{
The Advent of the Social Media and the Reconfiguration of Democracy: A South African Case Study
}

\author{
Dr. Abraham G. van der Vyver
}

\begin{abstract}
The advent of the social media has not only created several new platforms for citizens to share their view on political and/or polemic issues, it has also led to the reconfiguration of democracy. In this paper the researcher did an analysis of a Twitter narrative on a controversial Cabinet reshuffle by the South African President, Mr. Jacob Zuma. The news broke on ANN7 after 9.30pm of 30 November 2017 that Zuma axed nine ministers and six deputy ministers. The official announcement only came after midnight.

The 12000 tweets that were captured included may reposts. A distinction was inter alia drawn between the tweets of professional and citizen journalists. The main emphasis of the study was thematic analysis.
\end{abstract}

Keywords-Actvism, professional journalism, citizen journalism.

\section{INTRODUCTION}

The South African President. Jacob Zuma's Cabinet reshuffle triggered on of the most vigorous social activism campaigns this decade. Thamm [1] reported "After a week of high drama, with the country on the edge of its collective seat and while the rand took another severe beating, President Jacob Zuma made an after-midnight announcement of his long-threatened Cabinet reshuffle." The removal of The Minister of Finance, Pravin Ghordan, and his deputy, Mcebisi Jonas, "on the strength of a fake "intelligence" report which EFF leader Julius Malema says looks like it was written by a child [2].

In his own version of the Hitler's Night of the Long Knives, Zuma has taken his biggest gamble of his career by firing five members of his cabinet and wapped the posts of five loyalists. Most telling, he has promoted numerous politicians known to have close ties to the crony capitalist Gupta family - and axed public critics of the Indian immigrants.[3]

\section{LITERATURE}

The social media has, by redefining social activism, also reconfigured democracy in that the digital media became an important driver in the launching and organizing of a campaign. A digital activism campaign is defined as "an organized public effort, making collective claim(s) on a target authority(s), in which civic initiators or supporters use digital media" Howard

Manuscript received on 22 September 2017.

Dr. A.G. van der Vyver is with Monash South Africa, 144 Peter Road, Ruimsig 1725.
[4]. Frame [5] pointed out that "(p)oliticians, voters and members of civic society now commonly make use of the Internet, blogs, mainstream tools (activist management platforms or specialised social networks) in relation with their political activity."

Yang [6] refers to hashtag activism which he explains is "meaning discursive protest on social media united through a hashtagged word, phrase or sentence." The hashtag applies to Twitter. "Twitter - a microblogging service that enables users to post messages ("tweets") of up to 140 characters - supports a variety of communicative practices; participants use Twitter to converse with individuals, groups, and the public at large" [7]. Hashtags serve as a metatag for grouping messages. By adding hashtags in tweeting, the visibility can be enhanced as the tweet becomes more searchable than in plain texts format [8].

Users can mention others when tweeting, such as influential public figures, media outlets, government organizations, or advocacy groups. They can also reply to others' tweets or repost them to propel conversation. Through building a real-time network of activism, users are able to share collective outrage and hope based on common objectives [9].

Twitter's uses have been extended beyond everyday "lifesharing" and interpersonal communication to similar journalistic, para-journalistic, and quasi-journalistic activities [10]. The flow of news and information has been altered from a society governed by a traditional mass media to one that has embraced more networked digital media technologies [11]. The commercial mass media have been forced to adopt platforms like Twitter to engage with audience members [11]. Tweets are often embedded in news reports to project the reaction of the citizenry on political and/or polemic issues. The rise in the use of social network platforms has produced a new breed of citizen or deliberative journalism, which puts the power to disseminate ideas, and to champion causes, in the hands of the general public [12]. Deliberative journalism sees citizens recognising the issues that affect their communities, formulating responses to these hurdles and strategising about how they should go about taking action [12].

Among the wide array of themes featuring in tweets that deal with politics or other issues of a polemic nature, emotions and jest always feature. Obadare [13] provided the following explanation within the context of African culture: T'oro ba $t i$ $k^{\prime}$ oja ekun, erin la fi $n$ rin (Laughter is the only adequate 
response to an extremely sorrowful situation (Yoruba proverb) [13]. Cartoons often contribute to the narrative relating to these issues. "Political cartoons function as a key indicator of the democratic health of a polity. These images provide individual, momentary insights into the expressions and experiences of power and the creative ways in which these are responded to Hammett [14].

\section{METHODOLOGY}

The researcher used the software tools nCapture and nVivo to capture and analyze 12000 tweets on the topic. A thematic and source analysis was subsequently conducted.

A distinction was drawn between citizen and professional journalists. Lindner, Connell and Meyer [15] define a professional journalist as a person with past or present occupational experience with a news organization that adheres to mainstream journalistic practices. "Citizen journalism is defined by a number of attributes which make it distinct from professional journalism, including unpaid work, absence of professional training, and often unedited publication of content, and may feature plain language, distinct story selection and news judgment, especially hyper-local issues, free accessibility, and interactivity" [16]. According to Harper [17] "the increasing presence, speed and accessibility of advanced cellular phones and other media sharing devices has allowed citizen journalists to report on breaking news not only to a larger, global, audience, but also more quickly than traditional news reporters."

Goode [18] raised what he called "the most vexing question about the boundaries of citizen journalism" namely "whether we should restrict its definition to practices in which citizens act as content creators, producing original news material." This question relates to other ways citizens voice an opinion or make a contribution to the news environment, e.g., by "rating, commenting, tagging and reposting", all acts of contribution that is seen as "considerably less significant than 'real' citizen journalism" [18]. Goode [18] explained that "if a user posts a comment on an existing news story but, in doing so, brings to light new knowledge about that event or topic, then it is not clear that this contribution can be classified only as 'metajournalism'." The amount of metajournalism generated by some of the tweets are indicated in the findings.

\section{FINDINGS}

\section{A. Professional Journalists, Citizen Journalists, And Important Personae.}

The tweets from journalists and their media houses mostly consisted of references to news reports or articles. This is an example from eNCA:

RT @eNCA: [LIVE BLOG] \#PravinGordhan removed as Finance Minister \#CabinetReshuffle_https://t.co/PiZM4tHkdE https://t.co/6zmnt fmdPd
This retweet of an Independent Online news report found its way too several other related hashtags. It was also retweeted by a well-known media activist, Yusuf Abramjee.

RT @IOL: Mayhem looms as \#AntiZumaMarches marches hit streets

@ Abramjee \#JunkStatus \#cabinetreshuffle \#ANCNWC \#NWC https://t.co/3MBJ85zoyS...

Media polling was also on the Twitter agenda. The HuffPost posted the following question:

RT @HuffPostSA: \#BlackMonday movement wants you to wear black tomorrow to protest \#CabinetReshuffle. Are you going to be joining? https://t...

A renowned freelance journalist Max du Preez posted this tweet:

The keys to the National Treasury, so long guarded bravely by Pravin Gordhan, have been handed over. There you go.

It generated 29 conversations, 308 retweets and 231 likes.

Du Preez has got 171000 followers.

Citizen journalists are not hampered by the ethical codes and conventions that apply to professional journalists. The following tweet proves this:

RT @IanCameron23: RETWEET if you think this tsotsi should be axed and prosecuted \#CabinetReshuffle \#reshuffle \#Gordhan \#Zuma \#Reshuffle \#Ca...

Politicians were among the Twitterati that responded to same of the changes in Cabinet. Floyd Shivambu from the EFF commented on the dubious intelligence report that President Zuma cited as a reason for the removal of Minister Ghordan and his deputy. His tweet read:

Here is the fake, Gupta manufactured 'intelligence' report that made Zuma recall Minister \& DM and threaten to fire them:

9:22 PM - Mar 29, 2017

It generated 168 conversations, 966 retweets and 575 likes.

Important personae from all over society commented on the reshuffle. Ziphozihle Siwa, Presiding Bishop of Methodist Church of Southern Africa posted:

RT @Chriseldalewis: \#CabinetReshuffle 'It is time for President Zuma to resign or be removed - Ziphozihle Siwa, Presiding Bishop of Method.

\section{B. Dominant Themes}

A wide array of themes was addressed in the tweets:

- An analysis of the situation

RT @ pmabuza1: Week of shame behind us, week of courage $\&$ active citizenship begins. \#cabinetreshuffle \#PravinGordhan - Jest

The announcement appeared in the media on 31 March, the day before April 1. It triggered the following response:

RT @ANATII: Too early for April Fool's day... When will enough be enough for South Africans? \#CabinetReshuffle

- Appeals

Several of the Twitterati used the platform to stage appeals. Here are some examples:

From Mcebisi Jonas, the sacked Deputy Minister of Finance who was one one of the victims of the reshuffle: 
RT @CathyMohlahlana: \#McebisiJonas sharing his words with protesters. "Defend the constitution" \#cabinetreshuffle https://t.co/iQELUwbTG5

- Religion

RT @iiAM_ChillyDzee: \#BlackMonday \#CabinetReshuffle Let Us Pray For our Country.

RT @Debora_Patta: \#Zuma's midnight \#CabinetReshuffle - the desperate act of a man who has sold his country for 30 pieces of silver to the h...

\section{- Foreign countries}

Some of the tweets referred to similar challenges in other countries. The following examples apply:

Ex-president of Egypt Mubarak was ousted in 18 days! We can do it SA! \#NoConfidence \#cabinetreshuffle \#zumamustfall \#Blackmonday

RT @ nanima: Wonder if we could have a south african spring \#cabinetreshuffle \#PravinGordhan \#Blackmonday https://t.co /3Vo9TYCVIt

- Condemnation

When @MYANC has even rewarded their members with promotions after scandals. Bunch of hypocrites \#CabinetReshuffle... https://t.co/KrFa9MyDSf

- Interpretation

RT @MbuyiseniNdlozi: No! This is not a \#cabinetreshuffle! This is a coup d'etat! It's a direct takeover of government by a mafia with no re...

\section{- Philosophy}

"Our lives begin to end the day we become silent about things that matter." - Dr Martin Luther Kin...

RT @eNCA: \#McebisiJonas "There is no struggle as hard as the struggle against your own." \#CabinetReshuffle https://t.co/HStiMJbLIC

RT @Lean3JvV: Dear Jacob Zuma,

The power of the people is greater than the people in power.

South Africa we must RISE!

\section{- Confusion}

RT @mzansi_facts: Gwede Mantashe last week : I'm not happy with \#CabinetReshuffle Mantashe this week : I'm happy,give \#Gigaba a chance

$$
- \text { Pol... }
$$

\section{- Defense}

RT @bonglez: @Lesiba_Mothata says it's not time to panic. Treasury is stronger than any single individual \#CarteBlanche \#cabinetreshuffle

- Nuclear deal

While we were all busy with \#cabinetreshuffle The Nuclear deal with Russia has been finalized, we are officially in... https://t.co/wI3HcxDilT

\section{- Cartoons}

The cartoon from Rico reflected the influence of the infamous Gupta family on the Cabinet Reshuffle by President Zuma.

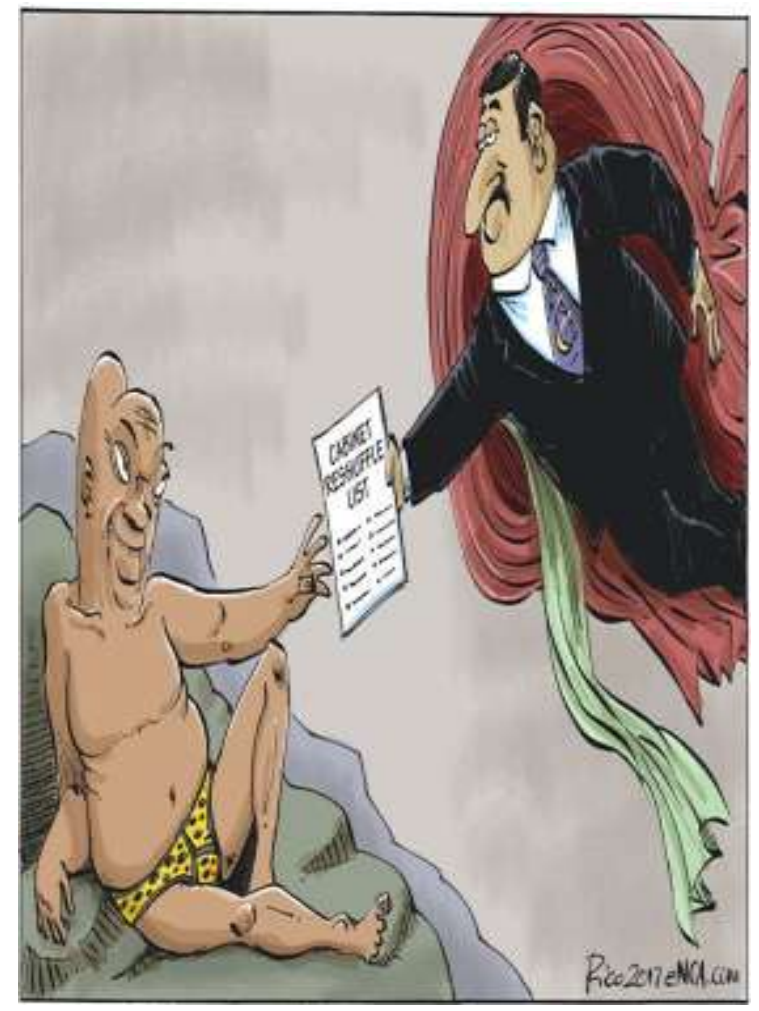

\section{CONCLUSION}

The Cabinet Reshuffle by President Jacob Zuma led to a public furore that manifested in a tsunami of tweets from all over the political spectrum. As with most of the political or polemical issues the tweets covered a wide array of themes and topics. Although many of the Twitterati did not contribute original content, they participated enthusiastically by liking and reposting the tweets of other users. This form of metajournalism contributed greatly in spreading the resistance message.

\section{REFERENCES}

[1] M. Thamm, "The axeman strikes: Pravin Gordhan sidelined in Zuma's late-night Cabinet reshuffle gamble," Daily Maverick, 31 March 2017.

[2] Maynier, D. Fake intelligence report must be investigated by the IGI, PoliticsWeb,

http://www.politicsweb.co.za/politics/fake-intelligence-reportmust-be-investigated-by-t 30 March 2017.

[3] Biznews, "\#Zumicon: Ghordan and others fired, Zuma cabinet full of gupta associates" https://www.biznews.com/leadership/2017/03/31/comment-zumas-night -of-long-knives-gordhan-out-gupta-associates-in/ 31 March 2017.

[4] P. Howard, "Report on digital activism and non-violent conflict," in Digital Activism Research Project, http://digital-activism.org/2013/11/report-on-digital-activism-and-non-v iolent-conflict/ 20 November, 2013.

[5] A. Frame, "Introduction," in Citizen Participation and Political Communication in a Digital World, A. Frame and G Brachotte (eds.) New York: Routledge, 2016.

[6] Yang, "Narrative agency in Hashtag Activism: the Case of \#BlackLivesMatter," Media and Communication, Vol 4(4), 2016.

[7] Boyd, D., Golder, S., \& Lotan, G. "Tweet, tweet, retweet: Conversational aspects of retweeting on Twitter", HICSS-43. IEEE: Kauai, HI, January 6, 2010. https://doi.org/10.1109/HICSS.2010.412

[8] Small, T. "What the hashtag? A connect analysis of Canadian politics on Twitter. Information", Communication \& Society 14(6): 872-895, 2011 https://doi.org/10.1080/1369118X.2011.554572 
[9] Allagui, I. and Kuebler, J., "The Arab Spring and the Role Of ICTs: Editorial Introduction". International Journal of Communication 5: 1435-1442, 2011.

[10] Subasic, I and Berendt, B. "Peddling or Creating? Investigating the role of Twitter in news reporting". In Advances in Information Retrieval, Edited

by: Clough, P., Foley, C., Gurrin, C., Jones, G., Kraaij, W., Lee, H. \& M udoch, V. 207-13. Berlin, Springer, 2011 https://doi.org/10.1007/978-3-642-20161-5_21

[11] Lotan, G., Ananny, M., Devin, G. \& Boyd, D. “The revolutions were tweeted: Information flows during the 2011 Tunisian and Egyptian revolutions", International Journal of Communication, 5, 1375-1405, 2011.

[12] Romano, A. International journalism and democracy: Civic engagement models from around the world. New York and London: Routledge, 2010.

[13] Obadare, E. "Resistance Through Ridicule (Africa)", Encyclopedia of Social Movement Media, pp.445-446, Thousand Oaks, CA, Sage, 2011.

[14] Hammett, D. "Political Cartoons, Post-Colonialism and Critical African Studies", in Critical African Studies, Vol. 2 (4), pp. 1-26 2010.

[15] Lindner, A.M., Connell, E \& Meyer, E. Professionaljournalists in 'citizen' journalism, Information, Communication \& Society, 2015 DOI:10.1080/1369118X.2015.1012530 https://doi.org/10.1080/1369118X.2015.1012530

[16] Kaufhold, K., Valenzuela, S., \& Zúñiga, H. G. De. "Citizen journalism and democracy: How user-generated news use relates to political knowledge and participation," in Journalism \& Mass Communication Quarterly, 87 (3/4), 515 - 529, 2010. https://doi.org/10.1177/107769901008700305

[17] Harper, A. "Citizen journalism vs. professional journalism", Journalism: The Future, https://journalismthefuture.wordpress.com/citizen-journalism-vs-profess ional-journalism/ (accessed 14 November 2015). n.d.

[18] GOODE, L. "SOCIAL NEWS, CITIZEN JOURNALISM AND DEMOCRACY", NEW MEDIA \& SOCIETY, VOL. 11, NO. 8, PP.1287-1305, 2009.

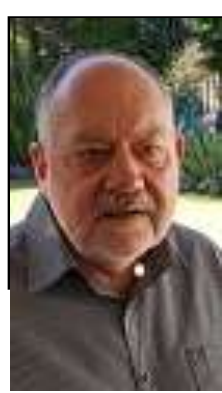

Dr. Abraham Gert van der Vyver has obtained degrees in law, marketing, communications and information systems. He has occupied management positions in all three spheres of government, a parastatal as well as in the private sector. He has got 20 years lecturing experience which includes 15 years at Monash, SA. He's research interests include development informatics and social informatics. 